\title{
ANALYSIS OF THE ENERGY EFFICIENCY OF THE CAMPO MOURÃO-PR MUNICIPAL LIBRARY: PARAMETERS OF THE NATIONAL LABELING PROGRAM (RTQ-C)
}

\section{ORIGINAL ARTICLE}

CARVALHO, Fanny Islana de Lima1, HALMEMAN, Maria Cristina Rodrigues², LERCO, Felipe Matos dos Santos ${ }^{3}$

CARVALHO, Fanny Islana de Lima. HALMEMAN, Maria Cristina Rodrigues. LERCO, Felipe Matos dos Santos. Analysis of the energy efficiency of the Campo Mourão-PR municipal library: parameters of the national labeling program (RTQ-C). Revista Científica Multidisciplinar Núcleo do Conhecimento. Year. 06, Ed. 10, Vol. 05, pp. 43-62. October 2021. ISSN: 2448-0959, Access Link: https://www.nucleodoconhecimento.com.br/environmental-engineering-en/municipallibrary, DOI: 10.32749/nucleodoconhecimento.com.br/environmental-engineeringen/municipal-library

\section{ABSTRACT}

The construction sector, responsible for environmental impacts such as waste generation, water and energy consumption, has as its current challenge to bring energy efficiency into the construction site and post-built environment. Thus, in relation to energy consumption, INMETRO developed a labeling program aimed at classifying the energy efficiency of electrical equipment and also buildings. It turns out that public buildings are required to obtain the National Energy Conservation Label (ENCE). Given the above, it is asked how to measure the energy efficiency of public buildings, making them energy-appropriate, and thus meet the needs of the

\footnotetext{
${ }^{1}$ Bachelor of Architecture and Urbanism. ORCID: 0000-0002-1871-2618.

${ }^{2}$ Bachelor of Civil Engineering. ORCID: 0000-0002-2809-6601.

${ }^{3} \mathrm{PhD}$ in Agronomic Sciences. ORCID: 0000-0001-6964-7572.
}

RC: 100244

Available in: https://www.nucleodoconhecimento.com.br/environmental-engineeringen/municipal-library 
user, providing environmental comfort and economy. The objective of this work was to simulate obtaining the ENCE Geral label and present the level of energy efficiency of the Municipal Library of Campo Mourão-PR. The Prescriptive Method was used, established by the Technical Quality Regulation for the Energy Efficiency Level of Commercial, Service and Public Buildings (RTQ-C). Three building systems were analyzed: Wrapping, Lighting System and Air Conditioning System. As a result, the building under study presented a level $C$ classification of efficiency, on a scale of $A$ $E$, being $A$ very efficient, and $E$ inefficient. It is concluded that the building does not provide comfort to users, besides high energy consumption. However, it is possible to adopt measures that can help optimize the level of energy efficiency on site.

Keywords: Wrapping, Lighting System, Air Conditioning, Prescriptive Method, Total Classification.

\section{INTRODUCTION}

The concern of developed countries with environmental conservation resulted in international conferences, seeking economic alternatives. (DEBATES INTERDISCIPLINARES VII, 2016).Examples of these conferences are the Kyoto Protocol and the Stockholm Convention. In the national scenario, from 2014 public buildings began to be obliged to present energy efficiency label (ENCE), as published in the Official Gazette by the Secretariat of Logistics and Technology of normative IN02/2014 (CONSELHO DE ARQUITETURA E URBANISMO/BR, 2014). In view of the above, the question arose about how it is possible to measure the energy efficiency of a public building, ensuring comfort and economy to users.

The Brazilian Labeling Program (PBE), together with the PBE Edifica, arose from discussions initiated by the National Institute of Metrology, Quality and Technology (INMETRO). The objective of this program is to raise consumer awareness through information about the operation of equipment and its energy consumption (CONFERÊNCIA DE ESTUDOS EM ENERGIA ELÉTRICA, 2019). This program

RC: 100244

Available in: https://www.nucleodoconhecimento.com.br/environmental-engineeringen/municipal-library 
developed the Technical Quality Regulation for the Level of Energy Efficiency of Residential Buildings (RTQ-R) and the Technical Quality Requirements for the Level of Energy Efficiency of Commercial, Service and Public Buildings (RTQ-C). The labeling system measures the level of energy efficiency on an "A - E" scale, being "A" more efficient, and "E" less efficient. RTQ-C evaluates buildings through two methods: Simulation Method (performed by software) and Prescriptive Method (made through equations).

There are four types of labels, which are: ENCE General (takes into account three building systems - Wrapping, lighting and air conditioning); ENCE Partial (independently evaluates each system); ENCE Simulation (obtained during the project phase); and ENCE Built Building (can be requested after obtaining the permit of the work or proven connections of electricity and gas by the concessionaires).

This article aimed to identify the level of Energy Efficiency of the Municipal Library simulating the obtaining of general ENCE. The analysis was developed in accordance with the 2017 RTQ-C Version 4 Application Manual. To achieve the general objective, this work was developed based on the following specific objectives: To observe the prerequisites required by the Manual for the Application of RTQ-C; collect data on site and process architectural design information; calculate and determine the level of energy efficiency for the three building systems.

\section{MATERIALS AND METHODS}

\subsection{MATERIALS}

The current Municipal Library Professor Egydio Martello is located in the central area of Campo Mourão-PR. The city has approximately 96,102 inhabitants (IBGE, 2020). Campo Mourão is a hub of COMCAM (Community of Municipalities of the Campo Mourão Region), which represents twenty-five municipalities, in this way, the city

RC: 100244

Available in: https://www.nucleodoconhecimento.com.br/environmental-engineeringen/municipal-library 
offers support for its microregion through medical care, education, industry and other areas.

Figure 01. Location of the Municipal Library.

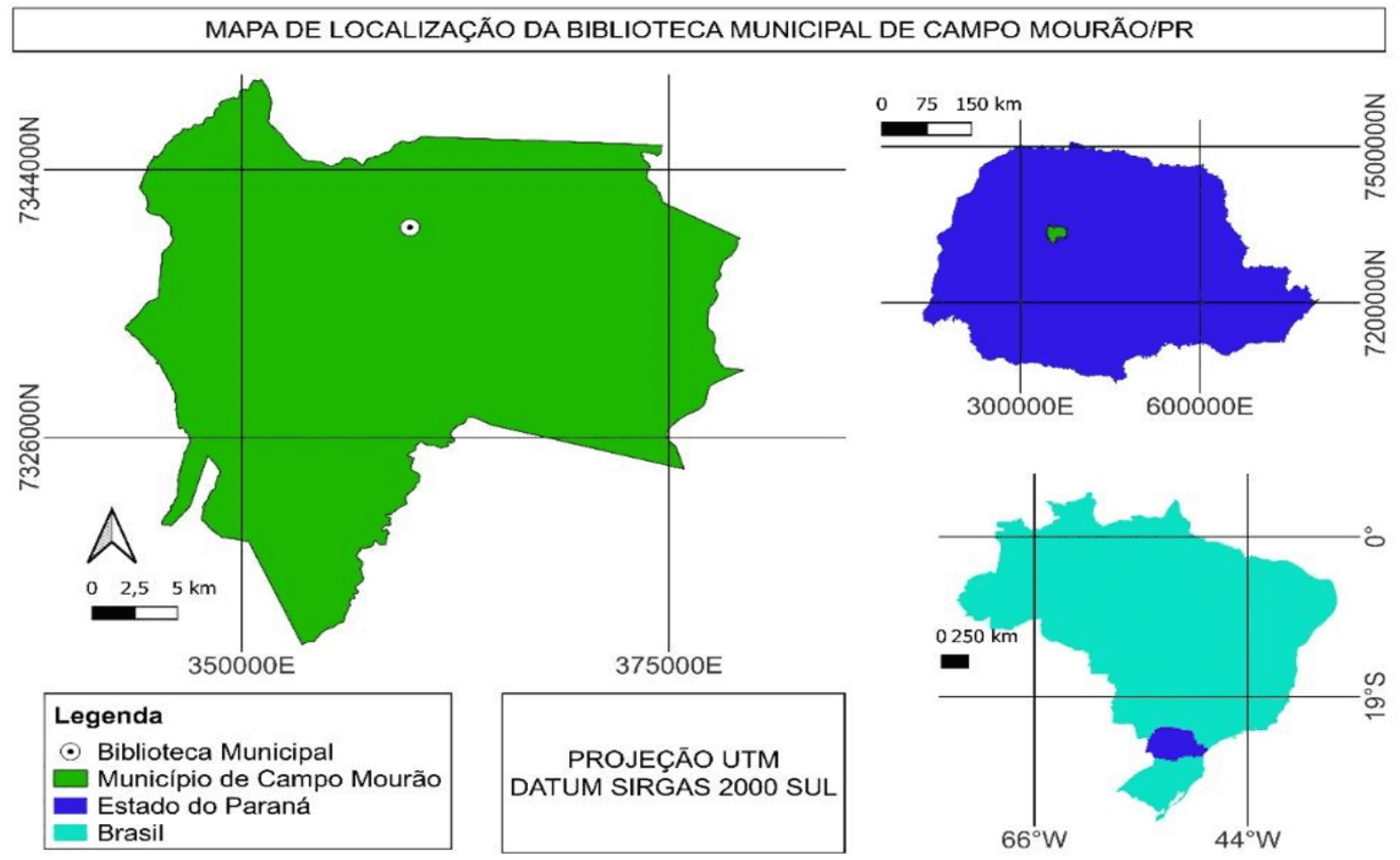

Source: Jairo Jerônimo de Campos Filho (2021).

The building under study has great historical relevance in the context of the development of the municipality, since it was originally designed to be the Bus Terminal. Subsequently, the building was adapted to house the library, which opened on December 30, 2004.

RC: 100244

Available in: https://www.nucleodoconhecimento.com.br/environmental-engineeringen/municipal-library 
Figure 02. Old Bus Station of Campo Mourão (A), current Municipal Library (B), Main Façade Municipal Library (C).

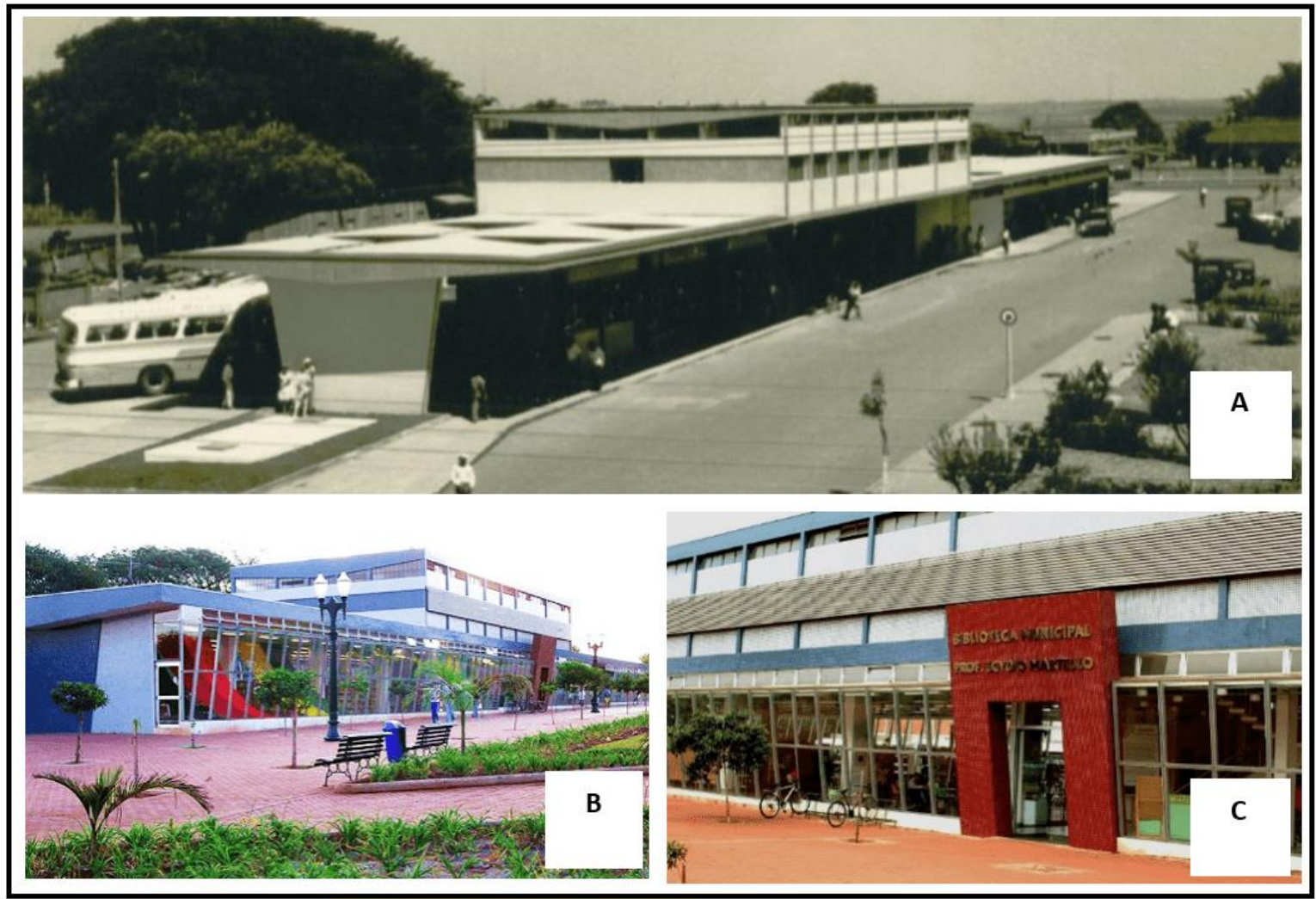

Source: (A) Personal collection of Jair Elias dos Santos Júnior (1969) and (B, C) collection of the Municipal Library Professor Egydio Martello (2007).

In addition to a vast collection, artistic exhibition space, ludoteca, and study areas, the library also houses the Mourãoense Academy of Letters. It is a linear building, with two floors, in reinforced concrete structure, with a total built area of $1772.92 \mathrm{~m}^{2}$, according to the layout of the Library in Figure 03. Much of its Wrapping consists of translucent glass curtains, which favors the unwanted heating of internal spaces. It is important to note that its main façade is facing the northeast direction, therefore, it receives a high incidence of solar radiation in the summer period.

RC: 100244

Available in: https://www.nucleodoconhecimento.com.br/environmental-engineeringen/municipal-library 
Figure 03. Layout Library Ground Floor (A), Offices Ground Floor (B), Superior Floor Library $(\mathrm{C})$.

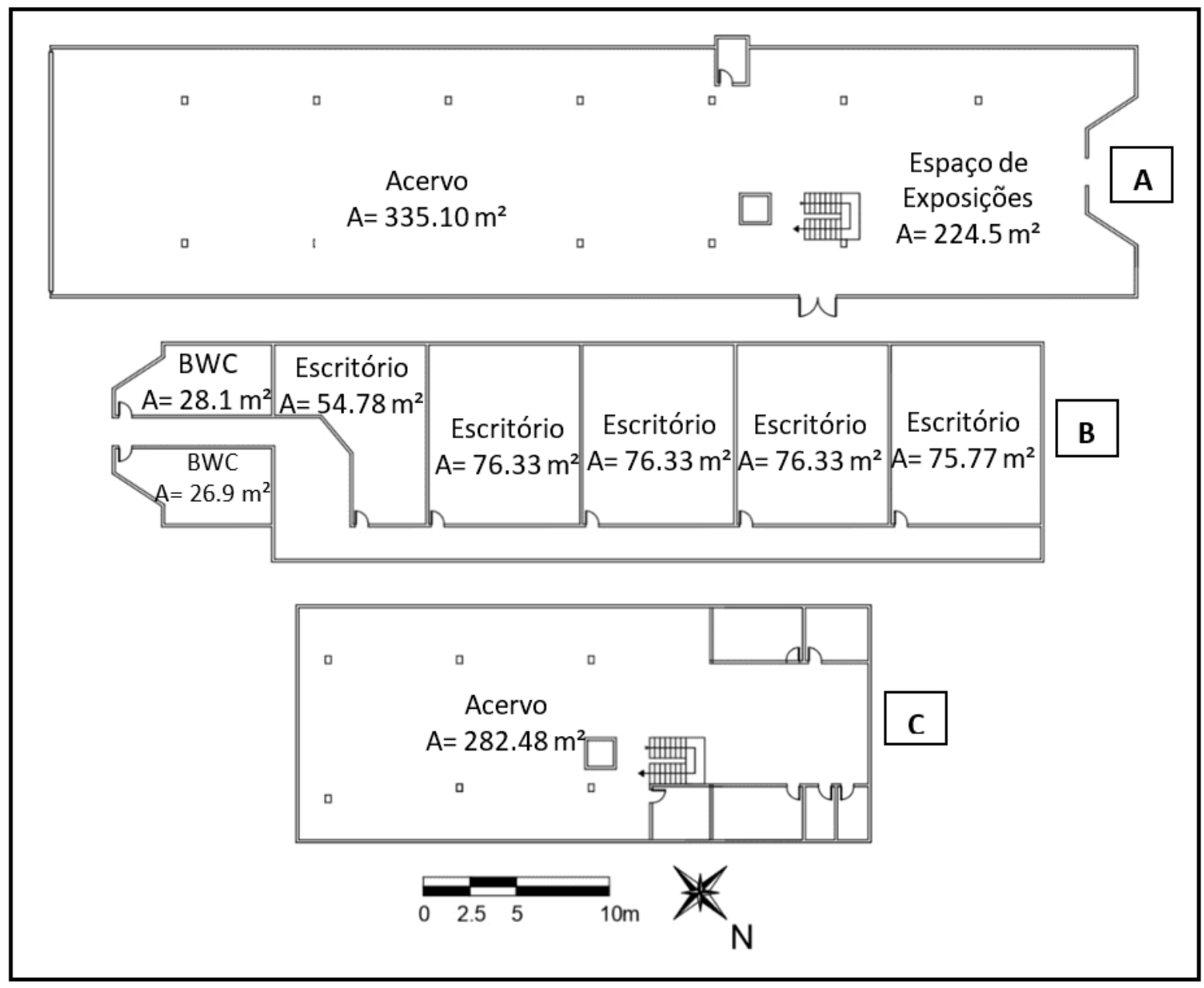

Source: Adapted from the original Architectural Project (2003).

\subsection{METHODS}

The method adopted for the present study is the prescriptive method, which applies only to conditioned buildings and evaluates energy efficiency through equations, according to the Bioclimatic Zone and the total area of the building. In order to obtain scores for the general ENCE label, three systems were analyzed: Wrapping, Lighting

RC: 100244

Available in: https://www.nucleodoconhecimento.com.br/environmental-engineeringen/municipal-library 
System and Air Conditioning. This methodology requires evaluation of general and system-specific prerequisites, which will be discussed below.

\subsubsection{GENERAL PREREQUISITES}

For levels $\mathrm{A}, \mathrm{B}$, and $\mathrm{C}$, there are two general prerequisites. Failure to comply with them impacts the final building score.

- The building must have a distinct electrical circuit for each use, be it air conditioning equipment, lamps or others. However, the Manual for Application of RTQ-C (2017) establishes that this item is not mandatory for buildings built before 2009, therefore, the building under study is exempt from it.

- Water Heating: This prerequisite applies only in commercial or service buildings, where hot water consumption is greater than $10 \%$ of total energy demand. In the case of the object of study, there is no installation of water heaters, therefore, this item does not apply.

\subsubsection{EQUATIONS FOR CALCULATION PROCEDURE}

In the process of individual classification of the systems, as well as for the general classification of efficiency, equations were used according to Table 01.

RC: 100244

Available in: https://www.nucleodoconhecimento.com.br/environmental-engineeringen/municipal-library 
Table 01. General Table of Equations.

\begin{tabular}{|c|c|c|}
\hline NOME & EQUAÇÃO & VARIÁVEIS \\
\hline $\begin{array}{c}\text { Equação } \\
01\end{array}$ & $\begin{array}{c}\text { IC env }=-14,14 \cdot \mathrm{FA}- \\
113,94 . \mathrm{FF}+50,82 . \mathrm{PAFtotal}+4,86 . \mathrm{FS}- \\
\text { 0,32.AVS+0,26.AHS- } \frac{35,75}{F F}- \\
\text { 0,54.PAFtotal.AHS }+277,98\end{array}$ & $\begin{array}{l}\text { IC env: Indicador de Consumo da } \\
\text { Envoltória. } \\
\text { Ape: Área de projeção do edifício } \\
\left(\mathrm{m}^{2}\right) \text {; } \\
\text { Ato }_{\mathrm{t}} \text { Área total construída }\left(\mathrm{m}^{2}\right) ; \\
\text { Aenv: Área da envoltória }\left(\mathrm{m}^{2}\right) ; \\
\text { Apcob: Área de projeção da } \\
\text { cobertura }\left(\mathrm{m}^{2}\right) ; \\
\text { AVS: Ângulo Vertical de } \\
\text { Sombreamento } \\
\text { AHS: Ângulo Horizontal de } \\
\text { Sombreamento } \\
\text { FF: Fator de Forma, (Aenv/ Vtot); } \\
\text { FA: Fator Altura, (Apcob/ Atot); } \\
\text { FS: Fator Solar; } \\
\text { PAF } \mathrm{T}: \text { Percentual de Abertura na } \\
\text { Fachada total: média do percentual } \\
\text { de aberturas existentes; }\end{array}$ \\
\hline
\end{tabular}

RC: 100244

Available in: https://www.nucleodoconhecimento.com.br/environmental-engineeringen/municipal-library 


\begin{tabular}{|c|c|c|}
\hline $\begin{array}{c}\text { Equação } \\
05\end{array}$ & $\begin{array}{l}\mathbf{P T}=0,3 \cdot\left\{\left(\text { EqNumEnv } \frac{A C}{A U}\right)+\right. \\
\left.\left(\frac{A P T}{A U} \cdot 5+\frac{A N C}{A U} \cdot \text { EqNu } \mathrm{mV}\right)\right\}+0,3 . \\
(\text { EqNumDPl })+0,4 \cdot\{(\text { EqNumCA } . \\
\left.\left.\frac{A C}{A U}\right)+\left(\frac{A P T}{A U} \cdot 5+\frac{A N C}{A U} \cdot \text { EqNumV }\right)\right\}+ \\
\mathrm{b}_{0}^{1}\end{array}$ & $\begin{array}{l}\text { EqNumEnv: Equivalente Numérico } \\
\text { Envoltória } \\
\text { AC: Área Condicionada } \\
\text { AU: Área útil } \\
\text { APT: Área de permanência } \\
\text { Transitória } \\
\text { ANC: Área não condicionada } \\
\text { EqNumV: Equivalente Numérico } \\
\text { Área Ventilada } \\
\text { EqNumDPI: Equivalente Numérico } \\
\text { Densidade de Potência Instalada } \\
\text { EqNumCa: Equivalente Numérico } \\
\text { Condicionamento de Ar } \\
\text { b: Bonificações }\end{array}$ \\
\hline & & $\begin{array}{l}\text { Vto }: \text { Volume total da edificação } \\
\left(\mathrm{m}^{3}\right) \text {; }\end{array}$ \\
\hline $\begin{array}{c}\text { Equação } \\
02\end{array}$ & $\mathbf{i}=\frac{I C \text { máx }-I C \text { mín }}{4}$ & $\begin{array}{l}\text { i: Intervalo } \\
\text { IC } \mathbf{C}_{\max } \text { Indicador de Consumo } \\
\text { máximo } \\
\text { IC } \mathbf{C}_{\min }: \text { Indicador de Consumo } \\
\text { Mínimo }\end{array}$ \\
\hline $\begin{array}{c}\text { Equação } \\
03\end{array}$ & $\mathbf{P}_{\text {lim }}=\mathrm{A}^{2}$. DPIL & $\begin{array}{l}\text { PI }_{\text {im: Potência Limite }} \\
\text { A: Área iluminada } \\
\text { DPIL: Densidade de Potência } \\
\text { Instalada Limite }\end{array}$ \\
\hline $\begin{array}{c}\text { Equação } \\
04\end{array}$ & EqNumCA $=\sum_{n=1}^{x}:\left[\begin{array}{l}\text { EqNumCA } \\
n\end{array} \frac{\text { Capn }}{\text { Capt }}\right]$ & $\begin{array}{l}\text { EqNumCA: Equivalente Numérico } \\
\text { de Condicionamento de } \mathrm{Ar} \\
\text { Capn: Capacidade de cada } \\
\text { sistema } \\
\text { Capt: Capacidade total dos } \\
\text { sistemas } \\
\text { x: Quantidade de sistemas }\end{array}$ \\
\hline
\end{tabular}

Source: Adapted from the Manual for Application for RTQ-C (2017).

\subsubsection{WRAPPING}

In order to meet the specific prerequisites of the envelomycin system, the values of the variables described in Chart 02 should be observed.

RC: 100244

Available in: https://www.nucleodoconhecimento.com.br/environmental-engineeringen/municipal-library 
Table 02. Specific Requirements for Wrapping - Zone 3.

\begin{tabular}{|c|c|c|c|c|c|c|}
\hline Nível & \multicolumn{3}{|c|}{ Transmitância Térmica (U) } & \multicolumn{2}{|c|}{$\begin{array}{c}\text { Cores e } \\
\text { Absortância } \\
\text { Térmica (a) }\end{array}$} & $\begin{array}{c}\text { Iluminação } \\
\text { Zenital }\end{array}$ \\
\hline \multirow{2}{*}{ - } & \multicolumn{2}{|c|}{ Cobertura } & Parede & Cobertura & Parede & \multirow{7}{*}{ N/A } \\
\hline & $\begin{array}{c}\text { Ambiente } \\
\text { Condicionado }\end{array}$ & $\begin{array}{l}\text { Ambiente não } \\
\text { condicionado }\end{array}$ & - & - & & \\
\hline A & $1.0 \mathrm{~W} / \mathrm{m}^{2} \mathrm{~K}$ & $2.0 \mathrm{~W} / \mathrm{m}^{2} \mathrm{~K}$ & $\begin{array}{c}3.7 \\
W / m^{2} k\end{array}$ & $<0.50$ & $<0.50$ & \\
\hline B & $1.5 \mathrm{~W} / \mathrm{m}^{2} \mathrm{k}$ & $2.0 \mathrm{~W} / \mathrm{m}^{2} \mathrm{~K}$ & $\begin{array}{c}3.7 \\
\mathrm{~W} / \mathrm{m}^{2} \mathrm{k}\end{array}$ & $<0.50$ & $\mathrm{~N} / \mathrm{A}$ & \\
\hline C & \multirow{2}{*}{\multicolumn{2}{|c|}{$2.0 \mathrm{~W} / \mathrm{m}^{2} \mathrm{~K}$}} & 3.7 & \multirow{3}{*}{\multicolumn{2}{|c|}{$\mathrm{N} / \mathrm{A}$}} & \\
\hline D & & & $\mathrm{W} / \mathrm{m}^{2} \mathrm{k}$ & & & \\
\hline E & \multicolumn{2}{|c|}{$>2.0 \mathrm{~W} / \mathrm{m}^{2} \mathrm{~K}$} & $\begin{array}{c}>3.7 \\
\mathrm{~W} / \mathrm{m}^{2} \mathrm{~K}\end{array}$ & & & \\
\hline
\end{tabular}

Source: Adapted from the RTQ-C Application Manual (2017).

ABNT NBR 15220-2 (2008) establishes parameters for the thermal performance of buildings. After verifying the attendance of the above values in accordance with the standard, it is necessary to observe the Bioclimatic Zone in which the object of study is inserted. According to Annex 1 of the Manual for Application of RTQ-C (2017), the city of Campo Mourão is in Bioclimatic Zone 3, as shown in Figure 04.

RC: 100244

Available in: https://www.nucleodoconhecimento.com.br/environmental-engineeringen/municipal-library 
Figure 04. Bioclimatic zoning of Brazil.

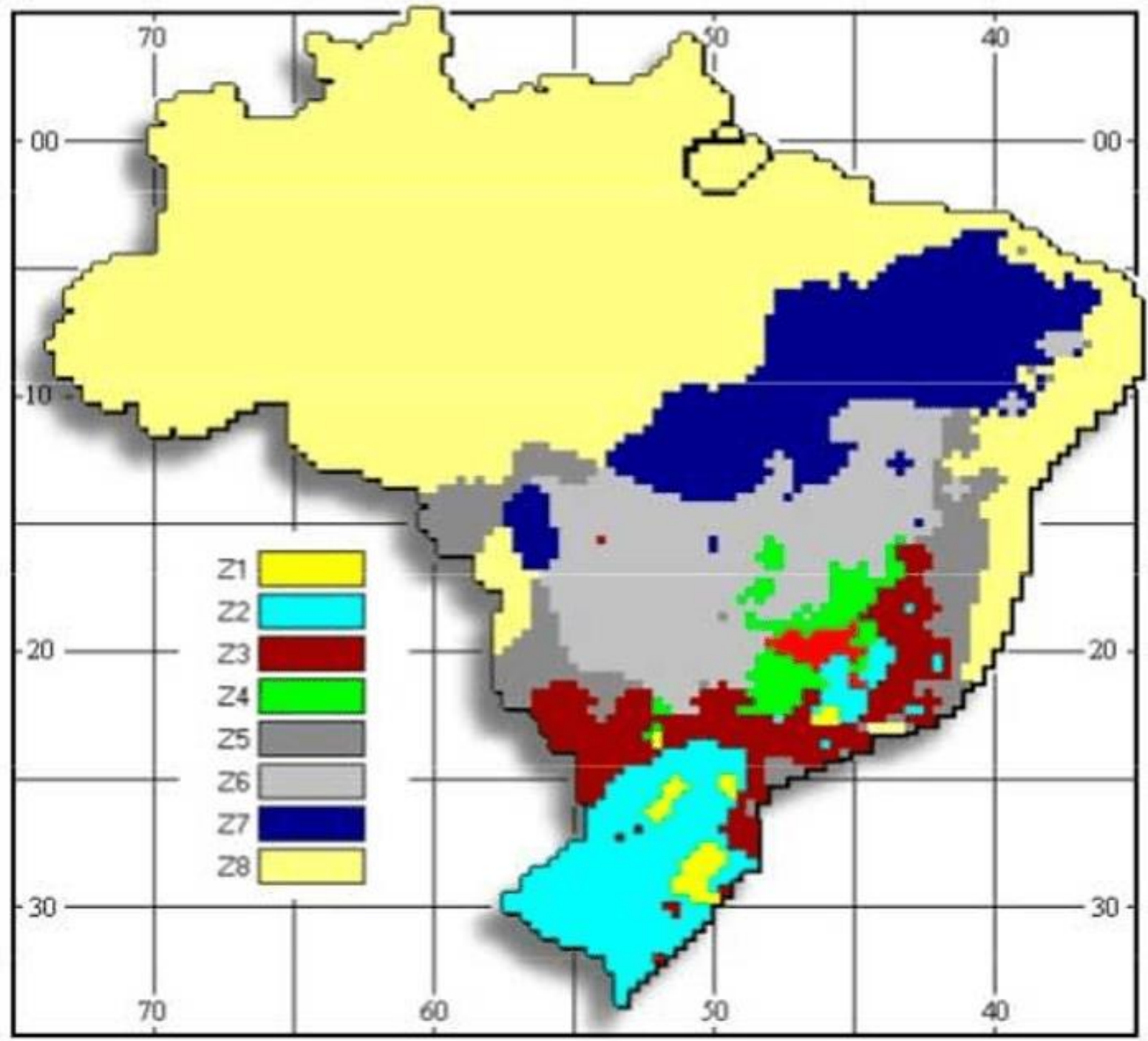

Source: Bioclimatism (2021).

For the calculation procedure, the information extracted from the architectural project and the variables according to Table 01 were necessary.

Considering that the Manual specifies different equations according to the area of the object of study, for areas greater than $500 \mathrm{~m}^{2}$ Equation 01 fits into the building.

RC: 100244

Available in: https://www.nucleodoconhecimento.com.br/environmental-engineeringen/municipal-library 
Soon after, the minimum IC and maximum IC were determined using the same equation, but with the input values according to Chart 03 .

Table 03. Maximum IC and minimum IC parameters.

\begin{tabular}{|l|c|c|c|c|}
\hline & PAF & FS & AVS & AHS \\
\hline IC máximo & 0,60 & 0,61 & 0 & 0 \\
\hline IC mínimo & 0,05 & 0,87 & 0 & 0 \\
\hline
\end{tabular}

Source: Manual for the application of RTQ-C (2017).

Therefore, the interval (i) of maximum IC and minimum IC was calculated by Equation 02. With the value of (i), table 04 was defined:

Table 04. Limits of the intervals of efficiency levels.

\begin{tabular}{|c|c|c|c|c|c|}
\hline Eficiência & A & B & C & D & E \\
\hline Lim. Mín. & N/A & $\begin{array}{c}\text { IC máx }- \\
3 i+0,01\end{array}$ & $\begin{array}{c}\text { IC máx }- \\
2 i+0,01\end{array}$ & $\begin{array}{c}\text { IC máx }-\mathrm{i} \\
+0,01\end{array}$ & $\begin{array}{c}\text { IC máx }+ \\
0,01\end{array}$ \\
\hline Lim. Máx. & $\begin{array}{c}\text { IC máx }- \\
3 i\end{array}$ & IC máx $-2 \mathrm{i}$ & IC máx $-\mathrm{i}$ & IC máx & N/A \\
\hline
\end{tabular}

Source: Manual for the application of RTQ-C (2017).

Finally, from the values in Table 04, the envelope IC value was compared with the maximum IC and minimum IC limits to identify the level of efficiency.

\subsubsection{LIGHTING SYSTEM}

The compliance with the specific prerequisites for the lighting system is described in Chart 05.

RC: 100244

Available in: https://www.nucleodoconhecimento.com.br/environmental-engineeringen/municipal-library 
Table 05. Prerequisites for lighting.

\begin{tabular}{|l|l|l|l|l|}
\hline Pré-Requisito & Nível A & Nível B & Nível C & Situação \\
\hline 1. Divisão dos circuitos & Exigido & Exigido & Exigido & Isento \\
\hline 2. Contribuição da luz natural & Exigido & Exigido & N/A & $\begin{array}{l}\text { Não } \\
\text { atende }\end{array}$ \\
\hline $\begin{array}{l}\text { 3. Desligamento automático } \\
\text { do sistema de iluminação }\end{array}$ & Exigido & N/A & N/A & $\begin{array}{l}\text { Não } \\
\text { atende }\end{array}$ \\
\hline
\end{tabular}

Source: Adapted from the RTQ-C Application Manual (2017).

The building under study is exempt from prerequisite number 1 , and does not meet the other prerequisites, so the level of the lighting system can automatically only have as maximum classification the level $\mathrm{C}$. However, its final classification is subject to the Installed Power Density Limit calculations.

There are two methods for calculating the efficiency of the lighting system:

- Area Method: Jointly evaluates environments (for buildings with 3 main activities, or activities that occupy more than $30 \%$ of the built area).

- Activity Method: Individually evaluates each activity.

Since the Municipal Library houses 3 main activities, and occupy more than $30 \%$ of the total area, we opted for the Area Method. The calculation procedure took place from the following steps:

a) The main activities were identified according to the Table of Acceptable Maximum Limit of Lighting Power Density (DPIL) for the desired efficiency level - Method of the building area, of the Manual for Application of RTQ-C (2017). For activities not described, an equivalent activity was chosen.

b) The area of each activity was identified, in square meters.

RC: 100244

Available in: https://www.nucleodoconhecimento.com.br/environmental-engineeringen/municipal-library 
c) Then, the limit power was defined for each activity, multiplying the area illuminated by the DPIL provided in the same Table of the Manual, according to Equation 03. From the limit power for each activity, the sum of the powers determined the limit power of the building.

d) Finally, the total power installed in the building was compared with the limit power to determine the level of efficiency of the lighting system using the Numerical Equivalent provided in Table 06.

Table 06. Numerical equivalent (EqNum) for each efficiency level.

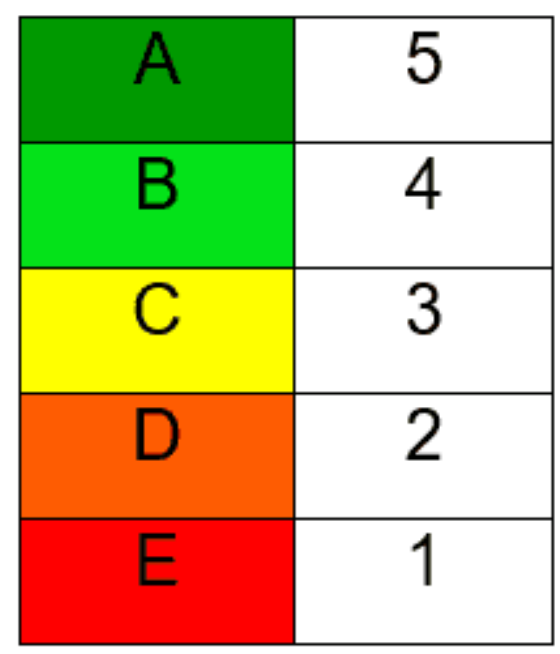

Source: RTQ-C Application Manual (2017).

\subsubsection{AIR CONDITIONING}

The air conditioning equipment installed in the Municipal Library is certified by INMETRO, so the technical information provided by the institute itself and the manufacturers was used. The procedure for determining the efficiency of the system was segregated in stages:

a) The efficiency of each system was observed through the label on the equipment.

RC: 100244

Available in: https://www.nucleodoconhecimento.com.br/environmental-engineeringen/municipal-library 
b) The Weighting Coefficient was determined by means of the ratio between the power of each unit and the sum of the powers of all units.

c) From the Weighting Coefficient multiplied by the Numerical Equivalent according to Table 06, the Weighted Result was obtained.

d) The sum of the Weighted Results of each unit determined the total efficiency, as expressed in Equation 04.

Because there are distinct efficiencies, the Air Conditioning system must have its Numerical Equivalent according to Table 07:

Table 07. Numerical Equivalent for Air Conditioning Systems and Overall Score.

\begin{tabular}{|c|c|}
\hline$A$ & $>4,5$ a 5 \\
\hline$B$ & $>3,5$ a $<4,5$ \\
\hline$C$ & $>2,5$ a $<3,5$ \\
\hline$D$ & $>1,5 a<2,5$ \\
\hline$E$ & $<1,5$ \\
\hline
\end{tabular}

Source: RTQ-C Application Manual (2017).

\subsubsection{TOTAL SCORE}

The determination of the total efficiency level of the building is expressed through Equation 05, which assigns weights for each system: 30\% for wrapping, 30\% for lighting system and $40 \%$ for air conditioning system. From the result of the equation,

RC: 100244

Available in: https://www.nucleodoconhecimento.com.br/environmental-engineeringen/municipal-library 
it is necessary to convert the numerical value determined for each level, as shown in Table 07.

\section{RESULTS AND DISCUSSION}

\subsection{WRAPPING}

To analyze the wrapping, it was first observed compliance with the specific prerequisites for this system. Table 08 demonstrates the score for each prerequisite.

Table 08. Compliance with Specific Prerequisites.

\begin{tabular}{|c|c|c|c|c|}
\hline \multirow{4}{*}{ Nível } & \multicolumn{2}{|c|}{ Transmitância Térmica (U) } & \multicolumn{2}{|c|}{$\begin{array}{c}\text { Cores e Absortância } \\
\text { Térmica }(\alpha)\end{array}$} \\
\hline & Cobertura & Parede & Cobertura & Parede \\
\hline & $\begin{array}{c}\text { Telha } \\
\text { fibrociment } \\
00.7 \mathrm{~cm} \mathrm{U} \\
=1.75 \mathrm{Wm}^{-} \\
{ }^{2} \mathrm{~K} \\
\end{array}$ & $\begin{array}{c}\text { Tijolo } 6 \text { furos } \\
\text { circulares, } \\
\text { assentados na } \\
\text { maior dimensão. U } \\
=1.88 \mathrm{Wm}^{-2} \mathrm{~K}\end{array}$ & $\begin{array}{l}\text { Telha } \\
\text { fibrociment } \\
\text { o } 0.7 \mathrm{~cm} \alpha \\
=0.30\end{array}$ & $\begin{array}{l}\text { Vidro Incolor } \\
\quad \alpha=0.25\end{array}$ \\
\hline & C & A & $A$ & $A$ \\
\hline
\end{tabular}

Source: Own authorship.

Next, the Consumption Indicator (IC) was determined according to Equation 01. Table 09 indicates the values for each variable, obtained from the architectural project.

RC: 100244

Available in: https://www.nucleodoconhecimento.com.br/environmental-engineeringen/municipal-library 
Table 09. Project Variables.

\begin{tabular}{|l|c|}
\hline \multicolumn{1}{|c|}{ Variáveis de Projeto } & Valores \\
\hline Ape: Área de projeção do edifício $\left(\mathrm{m}^{2}\right) ;$ & $799.97 \mathrm{~m}^{2}$ \\
\hline Atot: Área total construída $\left(\mathrm{m}^{2}\right) ;$ & $1599.95 \mathrm{~m}^{2}$ \\
\hline Aenv: Área da envoltória $\left(\mathrm{m}^{2}\right) ;$ & $2641.75 \mathrm{~m}^{2}$ \\
\hline Apcob: Área de projeção da cobertura $\left(\mathrm{m}^{2}\right) ;$ & $1280.13 \mathrm{~m}^{2}$ \\
\hline AVS: Ângulo Vertical de Sombreamento & $0^{*}$ \\
\hline AHS: Ângulo Horizontal de Sombreamento; & $0^{*}$ \\
\hline FF: Fator de Forma, (Aenv/ Vtot); & 0.401 \\
\hline FA: Fator Altura, (Apcob/ Atot); & 0.194 \\
\hline FS: Fator Solar; & 0.27 \\
\hline $\begin{array}{l}\text { PAFT: Percentual de Abertura na Fachada total: média do } \\
\text { percentual de aberturas existentes; }\end{array}$ & $34.76 \%$ \\
\hline Vtot: Volume total da edificação (m3 ); & $6575.15 \mathrm{~m}^{3}$ \\
\hline
\end{tabular}

Source: Own authorship.

* Null values, because the building does not present eaves, nor vertical elements of sun protection.

To determine the Solar Factor, the standard commercial glass for Cool Lite 114 PN 8 $\mathrm{mm}$ buildings was used, as specified in the Catalogue of Thermal and Optical Properties of Glasses Marketed in Brazil. After the calculation, the Envoltory Consumption Indicator (IC) equal to 159,373 was obtained as a result.

Then, the maximum IC (IC $\left.\mathrm{I}_{\max }\right)$ and minimum IC (IC $\left.\mathrm{C}_{\min }\right)$ were calculated, also using Equation 01, but substituting the values described in Table 04. As a result, it was concluded that $I C_{\max }$ is equal to 173.852 and $I C_{\min }$ is equal to 147,165 .

To calculate the Interval (i) $I C_{\max }$ and $I C_{\min }$, Equation 02 was applied, where the result obtained was 6,671 .

From the result of (i), the values of (i) of Table 05 were replaced by 6,671 , resulting in Table 10, which presents the minimum and maximum limits for each efficiency level.

RC: 100244

Available in: https://www.nucleodoconhecimento.com.br/environmental-engineeringen/municipal-library 
Table 10. Maximum and minimum ICenv values for each level.

\begin{tabular}{|c|c|c|c|c|c|}
\hline \multirow{5}{*}{ Mínimo } & A & $B$ & c & D & E \\
\hline & \multirow{4}{*}{$\mathrm{N} / \mathrm{A}$} & $\begin{array}{c}\text { IC máx }-3 i+ \\
0,01\end{array}$ & $\begin{array}{c}\text { IC máx }-2 i+ \\
0,01\end{array}$ & $\begin{array}{c}\text { IC máx - i + } \\
0,01\end{array}$ & IC máx + 0,01 \\
\hline & & $\begin{array}{c}173,852-3 \\
(6,671)+ \\
0,01\end{array}$ & $\begin{array}{c}173,852-2 \\
(6,671)+ \\
0,01\end{array}$ & $\begin{array}{c}173,852- \\
6,671+0,01\end{array}$ & $173,852+0,01$ \\
\hline & & $\begin{array}{c}173,852- \\
20,013+ \\
0,01\end{array}$ & $\begin{array}{c}173,852- \\
13,342+ \\
0,01\end{array}$ & \multirow[b]{2}{*}{167,191} & \multirow[b]{2}{*}{173,862} \\
\hline & & ${ }^{*} 153,849$ & 160,52 & & \\
\hline \multirow{5}{*}{ Máximo } & A & B & C & D & E \\
\hline & IC máx - 3i & IC máx $-2 \mathrm{i}$ & IC máx - i & IC máx & \multirow{4}{*}{$N / A$} \\
\hline & $\begin{array}{c}173,852-3 \\
(6,671)\end{array}$ & $\begin{array}{c}173,852-2 \\
(6,671)\end{array}$ & $\begin{array}{c}173,852- \\
6,671 \\
\end{array}$ & \multirow[b]{3}{*}{173,852} & \\
\hline & $\begin{array}{c}173,852- \\
20,013 \\
\end{array}$ & $\begin{array}{c}173,852- \\
13,342 \\
\end{array}$ & \multirow[b]{2}{*}{167,181} & & \\
\hline & 153,839 & ${ }^{*} 160,51$ & & & \\
\hline
\end{tabular}

Source: Own authorship.

* Actual value of the Library IC env with the limits found, where the Envelopment efficiency level is $B(160.51<159,373>153.849)$.

\subsection{LIGHTING SYSTEM}

To determine the level of efficiency of the Lighting System using the Area Method, the activities developed in each space of the Library were identified. The compliance with the prerequisites was observed individually for each environment, finally, the analysis of the system as a whole was performed through the sum of the DPIL of all environments. The calculation procedure was based on the information contained in Table 11.

RC: 100244

Available in: https://www.nucleodoconhecimento.com.br/environmental-engineeringen/municipal-library 
Table 11. Classification of the Lighting System.

\begin{tabular}{|c|c|c|c|c|c|}
\hline \multicolumn{2}{|l|}{ Atividade } & $\begin{array}{c}\text { Biblioteca } 1^{\circ} \\
\text { Pavimento }\end{array}$ & $\begin{array}{c}\text { Biblioteca } 2^{\circ} \\
\text { Pavimento }\end{array}$ & Escritório & $\begin{array}{c}\text { Total } \\
\text { Edifício* }\end{array}$ \\
\hline \multicolumn{2}{|l|}{ Área lluminada $\left(\mathrm{m}^{2}\right)$} & 559.6 & 282.48 & 359.63 & 1201.71 \\
\hline \multirow{4}{*}{ DPIL RTQ-C } & A & \multicolumn{2}{|c|}{12.7} & 9.7 & \multirow{4}{*}{$\mathrm{N} / \mathrm{A}$} \\
\hline & B & \multicolumn{2}{|c|}{14.6} & 11.2 & \\
\hline & C & \multicolumn{2}{|c|}{16.5} & 12.6 & \\
\hline & D & \multicolumn{2}{|c|}{18.4} & 14.1 & \\
\hline \multirow{2}{*}{ Lâmpadas } & $\begin{array}{l}40 \\
\text { W }\end{array}$ & 90 units & 104 units & 146 units & 340 \\
\hline & $\begin{array}{l}18 \\
W\end{array}$ & 142 units & 0 & 0 & 142 \\
\hline \multicolumn{2}{|c|}{ Potência Instalada (W) } & 6156 & 4160 & 5840 & 16156 \\
\hline \multirow{4}{*}{ Potência Limite (W) } & A & 7106.92 & 3587.49 & 3488.41 & 14182.82 \\
\hline & B & 8170.16 & 4124.2 & 4027.85 & 16322.21 \\
\hline & C & 9233.4 & 4660.92 & 4531.33 & 18425.65 \\
\hline & D & 10296.64 & 5197.63 & 5070.78 & 20565.05 \\
\hline \multicolumn{2}{|l|}{ Classificação Edifício } & \multicolumn{4}{|c|}{ Nível B } \\
\hline
\end{tabular}

Source: Own authorship.

* The Total Illuminated Area of the Building in square meters represents only the areas of prolonged stay, that is, does not include secondary areas such as, bathrooms, canopy, circulation and others. Since the equations described in the Manual for The Application of RTQ-C already predict a margin considering these secondary areas.

According to the DPIL calculations of each environment according to Equation 03, the Lighting System is classified as level B. However, considering that the building under study does not meet the prerequisites according to Chart 05 , the final score of the Lighting System drops to Level C.

RC: 100244

Available in: https://www.nucleodoconhecimento.com.br/environmental-engineering$\underline{\text { en/municipal-library }}$ 


\subsection{AIR CONDITIONING}

To determine the efficiency of the Air Conditioning system, the calculations were performed according to the methodology, and considering that all the air conditioning equipment of the Library are split ceiling type, the following results were obtained as shown in Chart 12.

Table 12. Air Conditioning System Classification.

\begin{tabular}{|c|c|c|c|c|c|c|}
\hline Ambiente & $\begin{array}{c}\text { Biblioteca 10 } \\
\text { Pavimento }\end{array}$ & $\begin{array}{c}\text { Biblioteca 2 } \\
\text { Pavimento }\end{array}$ & \multicolumn{3}{|c|}{ Escritório } \\
\hline Fabricante & ELGIN & ELGIN & GREE & RHEEM & KOMECO & AUSTIN \\
\hline Quantidade & 3 & 2 & 2 & 2 & 1 & 1 \\
\hline $\begin{array}{c}\text { Potência } \\
\text { (Btu/h) }\end{array}$ & 60000 & 60000 & 9000 & 20000 & 57000 & 60000 \\
\hline $\begin{array}{c}\text { Classificação } \\
\text { Energética }\end{array}$ & $\mathrm{C}$ & $\mathrm{C}$ & $\mathrm{A}$ & $\mathrm{D}$ & $\mathrm{D}$ & $\mathrm{D}$ \\
\hline $\begin{array}{c}\text { Equivalente } \\
\text { Numérico }\end{array}$ & 3 & 3 & 5 & 2 & 2 & 2 \\
\hline $\begin{array}{c}\text { Coeficiente } \\
\text { de }\end{array}$ & 0.22 & 0.22 & 0.03 & 0.07 & 0.21 & 0.22 \\
\hline $\begin{array}{c}\text { Ponderação } \\
\text { Resultado } \\
\text { Ponderado }\end{array}$ & 0.66 & 0.66 & 0.15 & 0.14 & 0.42 & 0.66 \\
\hline
\end{tabular}

Source: Own authorship.From the application of Equation 04, the result obtained was 2.69, which, according to Table 07 , is equivalent to level $C$ of efficiency.

\subsection{TOTAL SCORE (TS)}

To define the overall energy efficiency level of the building, the results of each individual system were synthesized in Equation 05. Table 13 shows the values for each variable used.

RC: 100244

Available in: https://www.nucleodoconhecimento.com.br/environmental-engineeringen/municipal-library 
Table 13. Equation variables 05.

\begin{tabular}{|l|c|}
\hline EqNumEnv & 4 \\
\hline AC & $1201,71 \mathrm{~m}^{2}$ \\
\hline AU & $1592,73 \mathrm{~m}^{2}$ \\
\hline APT & $182,86 \mathrm{~m}^{2}$ \\
\hline ANC & $\mathrm{N} / \mathrm{A}^{*}$ \\
\hline EqNumV & $\mathrm{N} / \mathrm{A}^{*}$ \\
\hline EqNumDPI & 4 \\
\hline EqNumCA & 3 \\
\hline B & ${\mathrm{N} / \mathrm{A}^{*}}$ \\
\hline
\end{tabular}

Source: Own authorship.

* Variables do not apply for conditioned environments.

The TS result was 3,111 , falling within the $\mathrm{C}$ level of energy efficiency.

\section{FINAL CONSIDERATIONS}

It is concluded that the Municipal Library of Campo Mourão does not present satisfactory results of energy efficiency. To optimize its efficiency, it is suggested:

- Intervention in the Wrap with installation of solar protection elements, such as horizontal and vertical eaves, brises, cobogós, among others.

- In relation to the Lighting System, it is recommended to divide the circuits, in a way that allows the shutdown of lamps near the windows for the use of natural light.

- As for the Air Conditioning System, it is important to replace the current equipment that does not have efficiency $A$, since $36 \%$ of the equipment has a D rating.

RC: 100244

Available in: https://www.nucleodoconhecimento.com.br/environmental-engineeringen/municipal-library 
- In addition to these measures, it is also recommended the replacement of fiber cement tiles by thermoacoustic tiles.

- To make the building more sustainable, it is advisable to install photovoltaic plates for solar power generation, since the initial investment is compensated in the short term, providing savings, low maintenance and functionality.

\section{REFERENCES}

ASSOCIAÇÃO BRASILEIRA DE NORMAS TÉCNICAS. NBR 15220-2: Desempenho térmico de edificações: Métodos de cálculo da transmitância térmica, da capacidade térmica, do atraso térmico e do fator solar de elementos e componentes de edificações. 2008.

CONSELHO DE ARQUIETURA E URBANISMO DO BRASIL (Brasil). Governo torna obrigatório que edifícios públicos federais tenham energia eficientes. Disponível em: https://www.caubr.gov.br/governo-torna-obrigatorio-que-edificiospublicos-federais-sejam-energeticamente-eficientes/\#comments. Acesso em: 28 ago. 2021.

CONFERÊNCIA DE ESTUdOS EM ENERGIA ELÉTRICA. PROGRAMA BRASILEIRO DE ETIQUETAGEM: Breve Panorama. Uberlândia, MG: Universidade Federal de Uberlândia, 2019. 5 p. Disponível em: https://www.lunasat.top/ceel/evento/artigos/\#2019. Acesso em: 28 ago. 2021.

CENTRO BRASILEIRO DE EFICIÊNCIA ENERGÉTICA EM EDIFICAÇÕES. Catálogo de Propriedades Térmicas e Óticas de Vidros Comercializados No Brasil. Brasil: Universidade Federal de Santa Catarina, 2015. Disponível em: https://cb3e.ufsc.br/sites/default/files/projetos/etiquetagem/catalogopropriedades-vidros-comercializados-brasil-13032015_v2.pdf. Acesso em: 28 jul. 2021.

RC: 100244

Available in: https://www.nucleodoconhecimento.com.br/environmental-engineeringen/municipal-library 
DOS SANTOS JUNIOR, J.E. Antiga Rodoviária de Campo Mourão-PR. 1969. Fotografia.

FILHO, Jairo Jerônimo De Campos. Mapa Localização Biblioteca. Campo Mourão: 2021. Mapa em escala gráfica. Software QGIS V. 3.2.

Programa Nacional De Conservação De Energia Elétrica. Manual para aplicação do RTQ-C. 4 ed. Brasil, 2017.

HARADA, Magali. Bioclimatismo: Blog de Arquitetura Bioclimática. Disponível em: http://bioclimatismo.com.br/bioclimatismo/zoneamento-bioclimatico-brasileiro/. Acesso em: 05 jun. 2021.

IBGE - INSTITUTO BRASILEIRO DE GEOGRAFIA E ESTATÍSTICA. Censo Brasileiro de 2020. Rio de Janeiro. 2021.

DEBATES INTERDISCIPLINARES VII. O Papel das Conferências Internacionais Sobre o Meio Ambiente Para o Desenvolvimento dos Regimes Internacionais Ambientais: De Estocolmo A Rio +20. Palhoça, Sc: Unisul, 2016. Disponível em: https://www.researchgate.net/profile/Jose-Baltazar-Andrade-

Guerra/publication/301626018_Debates_Interdisciplinares_VII/links/571e496f08aeac ed7889df5e/Debates-Interdisciplinares-VII.pdf\#page=168. Acesso em: 20 ago. 2021.

Submitted: August, 2021.

Approved: October, 2021.

RC: 100244

Available in: https://www.nucleodoconhecimento.com.br/environmental-engineeringen/municipal-library 